\title{
Analyzing PSU's Performance: A Case from Ministry of Petroleum and Natural Gas of India
}

\author{
Chia-Nan Wang, Lei-Chuan Lin, and Dhanabalan Murugesan \\ Department of Industrial Engineering and Management, National Kaohsiung University of Applied Sciences (KUAS), \\ Kaohsiung 80778, Taiwan
}

Correspondence should be addressed to Lei-Chuan Lin; leichuan@mail.mirdc.org.tw

Received 14 September 2013; Accepted 3 October 2013

Academic Editor: Teen-Hang Meen

Copyright (c) 2013 Chia-Nan Wang et al. This is an open access article distributed under the Creative Commons Attribution License, which permits unrestricted use, distribution, and reproduction in any medium, provided the original work is properly cited.

\begin{abstract}
The high economic growth in the past few years and increasing industrialization coupled with a burgeoning population have created a lot of concern for India's energy scenario. India's crude oil production has not shown significant growth in the last 10 or more years whereas its refining capacity has grown by more than $20 \%$ over the last 5 years. Oil consumption is growing at approximately $4.1 \%$ per year and natural gas consumption is growing at $68 \%$ per year. Therefore, evaluation performances and pushing energy companies to improve become important issues. The purpose of this research is of evaluation the performance of Indian energy industry under multiple different inputs and outputs criteria. The data envelopment analysis (DEA) and grey theory are used to conduct this study. There are total 14 public sector undertakings (PSUs) under this industry and no any private company. However, only 10 of them are mature enough to be published in India stock markets. Therefore, the realistic data of all 10 companies are used for this evaluation. The results demonstrate that Gas Authority of India Limited (GAIL), Chennai Petroleum Corporation Limited (CPCL), and Oil India Limited (OIL) are the top 3 of ranking influences. This integrated numerical study gives a better "past-present-future" insights into evaluation performance in India energy industry.
\end{abstract}

\section{Introduction}

According to Vlasblom et al. [1], Indian economy is estimated to grow at 6.9 per cent in 2011-12 as compared to the growth rate of 8.4 per cent in 2010-11. These GDP figures are based on factor cost at constant (2004-5) prices in 2011-12. The growth rate of 6.9 per cent in GDP during 2011-12 has been due to the growth rates of over 8 per cent in the sectors of electricity, gas and water supply, trade, hotels, transport and communication, and financing, insurance, real estate, and business services.

Eichengreen and Tong [2] argue that in 2007 India's share of global output was only $2.2 \%$. Furthermore, rapid trade growth in Asia has been supported by large investment flows. The fact that India has not made any major breakthrough in the field of renewable sources of energy, oil and, natural gas would continue to hold a place of key importance in India's economy.

van Ruijven and van Vuuren [3] said, "India has been growing at a decent rate annually and is committed to accelerating the growth momentum in the years to come. This would translate into India's energy needs growing many times in the years to come. Hence, there is an emphasized need for wider and more intensive exploration for new finds, more efficient and effective recovery, a more rational and optimally balanced global price regime-against the rather wide upward fluctuations of recent times, and a spirit of equitable common benefit in global energy cooperation."

Performance evaluation is the important approach for enterprises to give incentive and restraint to their operators and it is also an important channel for enterprise stakeholders to get the performance information [4]. There has been numerous and successful research related to data envelopment analysis (DEA) and grey systems theory in various industries going on ranging from products to services and other important fields today. In this research, we will provide some insights after getting combined results of DEA and Grey Systems theory. Using DEA methodologies, we input some performance attributes and classify them as inputs and outputs and then use them for DEA researches. For ranking industries, we have used super SBM method and followed by 
MPI for measuring the productivity indexes over the 5 year time frame from March 2008 to March 2012 (latest year).

The Ministry of Petroleum and Natural Gas initiated a new plan called New Exploration Licensing Policy (NLEP). It provides an international class fiscal and contract framework for exploration and production of hydrocarbons. In the first seven rounds of NELP from 2000 to 2009, production sharing contracts (PSCs) for 203 exploration blocks have been signed. Under NELP, 70 oil and gas discoveries have been made by private/joint venture (JV) companies in 20 blocks.

The purposes of this study are to rand the companies of the petroleum and natural gas sector public sector undertakings (PSUs), Government of India using Data Envelopment Analysis (DEA) model known as "Slack-based super SMB, Output oriented, Variable returns to scale" by their efficiency score levels, performance score levels, efficiency changes, and productivity index changes over the last 5 consecutive period years (from 2008 to 2012) by means of DEA based MPI (Malmquist Productivity Index).

\section{Literature Review}

Lahiani et al. [5] mention that in modern era with the development of Indian economy and rapid expansion of trade, the small scale industrial sector has emerged as a vibrant and dynamic segment in the process of industrialization, which is considered not only as a key factor to lift up the per capita income but also as a vital mechanism for a larger transformation of Indian economy.

Nomikos and Pouliasis [6] made an article which tries to assess the utilization efficiency of capacity of Indian rubber industry in terms of econometric framework for the period 1979-80 to 2008-09. The result suggests that there has been declining growth rate of capacity utilization in rubber industry of India during the postreforms period accompanied by declining output growth as well as capacity growth.

Cooper et al. [7] expanded Farrell $[8,9]$ efficiency measurement concept of multiple inputs and single output to the concept of multiple inputs and multiple outputs, utilized linear combination to convert it to single virtual input and output, estimated efficiency frontier from the ratio of two linear combinations, and measured the relative efficiency of each DMU in CRS, which is between 0 and 1 and can determine whether a DMU is inconstant, increasing or decreasing returns to scale.

Lai and Wei [10] recently have developed a process, based on data envelopment analysis (DEA) to evaluate and rank the relative importance of key performance indices (KPIs). The relative importance of each KPI is evaluated by performance loss measure, and each KPI is weighted according to the measure. Then, the relative performance of each unit is the ratio of weighted output to weighted input based on the common weights.

The super SBM model is adopted by Lo and Lu [11] and they have argued the reasons for using super SMB models. According to them, in contrast to the CCR and BCC measures, which are based on the proportional reduction in input vectors or the increase in output vectors without taking slacks into account, the SBM deals directly with input excesses and output shortfalls (slacks). The SBM reports an efficiency measure between 0 and 1 and gives an efficiency score of one if and only if the DMU concerned is on the frontier of the production possibility set with no input/output slacks. Furthermore, the SBM model possesses several desirable properties that can properly handle our research interests. For instance, this measure is unit invariant and monotone decreasing with respect to input excesses and output shortfalls; it is determined only by consulting the reference set of the DMUs and is not affected by statistics over the whole data set, and it is closely connected with other measures, for example, those in the CCR and BCC models and the Russell measure. On the other hand, the super efficiency SBM is particularly useful in distinguishing efficient DMUs when the number of DMUs is small compared with the number of evaluation criteria. Liu et al. [12] have studied the power generation efficiency of major thermal power plants in Taiwan during 2004-2006 using the data envelopment analysis (DEA) approach. A stability test was conducted to verify the stability of the DEA model. According to the results, all power plants studied achieved acceptable overall operational efficiencies during 2004-2006, and the combination.

The problem of measuring productive efficiency of an industry is very important to both economic theorist and a policy maker [8].

\section{Methodology}

3.1. Data Collection. The sample of this study is collected from a market observation posting website in India. This website contains the detailed stock market data of major stock markets like Bombay Stock Exchange (BSE) and National Stock Exchange (NSE). The realistic financial data collected in our study is taken from getting into the individual companies after making sure that they were listed in either of 2 major stock exchanges of India. So in our study, we have probed the required financial statements and the corresponding Evaluation attributes (total assets, total expenses, employee cost, total income, and operating profit were taken for this study) are collected and tabled for data analysis.

Even though there are 14 companies of this industrial segment directly under the control of Government of India, some of them have not been listed on either of the major stock exchanges like Bombay Stock Exchange (BSE) and National Stock Exchange (NSE). Therefore, this study skips those unlisted companies for our study consideration. The final selected companies taken for this research, the type of Industry, or business they are involved in and their stock exchange index numbers are listed in the following table. These following alphabetical order (Table 1 ) of 10 companies were named DMU1 to DMU10 accordingly. We follow this naming scheme on these companies throughout this study. We follow the same naming scheme even while applying the grey systems theory methods just for the sake of convenience.

According to Ittner and Larcker [13], Five factors, total assets, total expenses, employee cost, total income, and operating profit, are considered as the key financial indicators directly contributing to the performance of the industry. 
TABLE 1: List of final selected companies and naming scheme.

\begin{tabular}{|c|c|c|c|c|}
\hline Serial no. & $\begin{array}{l}\text { Naming } \\
\text { scheme }\end{array}$ & Name & Type of industry or business & Financial index symbols \\
\hline 1 & DMU 1 & Balmer Lawrie and Company & Packaging & $\begin{array}{c}\text { BSE: } 523319 \\
\text { NSE: BALMLAWRIE } \\
\text { ISIN: INE164A01016 }\end{array}$ \\
\hline 2 & DMU 2 & $\begin{array}{l}\text { Bharat Petroleum Corporation limited } \\
\text { (BPCL) }\end{array}$ & Refineries & $\begin{array}{c}\text { BSE: } 500547 \\
\text { NSE: BPCL } \\
\text { ISIN: INE029A01011 }\end{array}$ \\
\hline 3 & DMU 3 & $\begin{array}{c}\text { Chennai Petroleum Corporation } \\
\text { Limited (CPCL) }\end{array}$ & Refineries & $\begin{array}{c}\text { BSE: } 500110 \\
\text { NSE: CHENNPETRO } \\
\text { ISIN: INE178A01016 }\end{array}$ \\
\hline 4 & DMU 4 & Engineers India Limited (EIL) & Engineering & $\begin{array}{c}\text { BSE: } 532178 \\
\text { NSE: ENGINERSIN } \\
\text { ISIN: INE510A01028 }\end{array}$ \\
\hline 5 & DMU 5 & Gas Authority of India Limited (GAIL) & Oil drilling and exploration & $\begin{array}{c}\text { BSE: } 532155 \\
\text { NSE: GAIL } \\
\text { ISIN: INE129A01019 }\end{array}$ \\
\hline 6 & DMU 6 & $\begin{array}{l}\text { Hindustan Petroleum Corporation } \\
\text { (HPCL) }\end{array}$ & Refineries & $\begin{array}{c}\text { BSE: } 500104 \\
\text { NSE: HINDPETRO } \\
\text { ISIN: INE094A01015 }\end{array}$ \\
\hline 7 & DMU 7 & Indian Oil Corporation Limited (IOC) & Refineries & $\begin{array}{c}\text { BSE: } 530965 \\
\text { NSE: IOC } \\
\text { ISIN: INE242A01010 }\end{array}$ \\
\hline 8 & DMU 8 & $\begin{array}{l}\text { Oil and Natural Gas Corporation } \\
\text { (ONGC) }\end{array}$ & Oil drilling and exploration & $\begin{array}{c}\text { BSE: } 500312 \\
\text { NSE: ONGC } \\
\text { ISIN: INE213A01029 }\end{array}$ \\
\hline 9 & DMU 9 & Oil India Limited (OIL) & Oil drilling and exploration & $\begin{array}{c}\text { BSE: } 533106 \\
\text { NSE: OIL } \\
\text { ISIN: INE274J01014 }\end{array}$ \\
\hline 10 & DMU 10 & $\begin{array}{l}\text { Mangalore Refineries and } \\
\text { Petrochemicals Ltd. (MRPL) }\end{array}$ & Refineries & $\begin{array}{c}\text { BSE: } 500109 \\
\text { NSE: MRPL } \\
\text { ISIN: INE103A010114 }\end{array}$ \\
\hline
\end{tabular}

3.2. DEA and Nonradial Super Efficiency Model (Super SBM). DEA was first proposed in 1978 by Charnes, Cooper, and Rhodes, (CCR) and is based on the technical efficiency measurement theories proposed by Farrell [8], using mathematical programming methods to measure the productivity boundaries of the unit to be evaluated and calculate the relative efficiency of each individual unit. Since the formal definition of the method, several scholars have proposed revisions to the theory and expansions of its application.

In pervious study, the technical efficiency change component of Malmquist productivity index is calculated by CCR score for the two periods. Because the CCR score is a radical measure, it takes no account of slacks. Instead of a radial based model, we now use the slacks based (nonradial) measure of superefficiency model to calculate technical efficiency change. The model takes account of slacks, and it has more accurate measurement.

In this study, a DEA model "Slacks-based measure of super efficiency" was used. This model was developed on "Slacks-based measure of efficiency" (SBM) introduced by Tone [14]. In this model with $n$ DMUs with the input and output matrices $X=\left(x_{i j}\right) \in R^{m \times n}$ and $Y=\left(Y_{i j}\right) \in R^{s \times n}$, respectively. $\lambda$ is a nonnegative vector in $R^{n}$. The vectors $S^{-} \in R^{m}$ and $S^{+} \in R^{s}$ indicate the input excess and output shortfall, respectively. SBM model in fractional form is as follows [14]:

$$
\begin{gathered}
\min \rho=\frac{1-(1 / m) \sum_{i=1}^{m} s_{i}^{-} / x_{i 0}}{1+(1 / s) \sum_{i=1}^{s} s_{i}^{-} / y_{i 0}}, \\
\text { subject to } x_{0}=X \lambda+s^{-}, \\
y_{0}=Y \lambda-s^{+}, \\
\lambda \geq 0, s^{-} \geq 0, s^{+} \geq 0 .
\end{gathered}
$$

Let an optimal solution for SBM be $\left(p^{*}, \lambda^{*}, s^{-*}, s^{+*}\right)$. A $\operatorname{DMU}\left(x_{0}, y_{0}\right)$ is SBM efficient, if $p^{*}=1$. This condition is equivalent to $S^{-*}=0$ and $S^{+*}=0$, no input excesses and no output shortfalls in any optimal solution. SBM is nonradial and deals with input/output slacks directly. The SBM returns and efficiency measure between 0 and 1 .

The best performers have the full efficient status denoted by unity. Tone [15] discriminated these efficient DMUs and ranked the efficient DMUs by superSBM model. Assuming 
that the DMU $\left(x_{0}, y_{0}\right)$ is SBM-efficient, $p^{*}=1$, super SBM model is as follows:

$$
\begin{array}{r}
\min \delta=\frac{(1 / m) \sum_{i=1}^{m} \bar{x}_{i} / x_{i 0}}{(1 / s) \sum_{r=1}^{s} \overline{y_{r}} / y_{r 0}} \\
\text { subject to } \bar{x} \geq \sum_{j=1, \neq 0}^{n} \lambda_{j} x_{j}, \\
\bar{y} \leq \sum_{j=1, \neq 0}^{n} \lambda_{j} x_{j}, \\
\bar{y} \geq x_{0}, \bar{y} \leq y_{0}, \\
\bar{y} \bar{y} \geq y_{0}, \lambda \geq 0 .
\end{array}
$$

As in many DEA models, it is crucial to consider how to deal with negative outputs in the evaluation of efficiency in SBM models too. However, negative data should have their duly role in measuring efficiency; hence, a new scheme was introduced in DEA-Solver pro 4.1 Manuel and the scheme was changed as follows.

Let us suppose $y_{r 0} \leq 0$. It is defined $\bar{y}_{r}^{+}$and $y_{-r}^{+}$by

$$
\begin{aligned}
& \bar{y}_{r}^{+}=\max _{j=1, \ldots, n}\left\{y_{r j} \mid y_{r j}>0\right\}, \\
& \bar{y}_{-r}^{+}=\min _{j=1, \ldots, n}\left\{y_{r j} \mid y_{r j}>0\right\} .
\end{aligned}
$$

If the output $r$ has no positive elements, then it is defined as $\bar{y}_{r}^{+}=y_{-r}^{+}=1$. The term is replaced $s_{r}^{+} / y_{r 0}$ in the objective function in the following way. The value $y_{r 0}$ is never changed in the constraints.

(1) $\bar{y}_{r}^{+}=y_{-r}^{+}=1$, and the term is replaced by

$$
\frac{s_{r}^{+}}{y_{-r}^{+}\left(\bar{y}_{r}^{+}-y_{-r}^{+}\right) /\left(\bar{y}_{r}^{+}-y_{r 0}\right)} .
$$

(2) Consider

$$
\frac{s_{r}^{+}}{\left(\bar{y}_{-r}^{+}\right)^{2} / B\left(\bar{y}_{r}^{+}-y_{r 0}\right)},
$$

where $B$ is a large positive number, (in DEA-Solver $B=100)$.

In any case, the denominator is positive and strictly less than $y_{-r}^{+}$. Furthermore, it is inverse proportion to the distance $\bar{y}_{r}^{+}-y_{r 0}$. This scheme, therefore, concerns the magnitude of the nonpositive output positively. The score obtained is units invariant; that is, it is independent of the units of measurement used.

3.3. Malmquist Productivity Index (MPI). Malmquist productivity index of productivity change is a multiplicative composite of efficiency and technical change as the major cause of productivity improvements can be ascertained by comparing the values of the efficiency change and technique change indexes. Put differently, the productivity losses described can be the result of either efficiency declines, or technique regresses, or both.

The output based Malmquist productivity index is defined as follows [16]:

$$
\mathrm{MPI}=\left[\frac{d_{o}^{s}\left(x_{t}, y_{t}\right)}{d_{o}^{s}\left(x_{s}, y_{s}\right)} \times \frac{d_{o}^{t}\left(x_{t}, y_{t}\right)}{d_{o}^{t}\left(x_{s}, y_{s}\right)}\right]^{1 / 2},
$$

where $d_{o}^{s}$ is a distance function measuring the efficiency of conversion of inputs $x_{s}$ to outputs $y_{s}$ in the period $s$. (Note that DEA efficiency is considered a distance measure in the literature as it reflects the efficiency of converting inputs to outputs [17].)

Importantly, if there is a technical change in period $t$, then

$$
\begin{aligned}
d_{o}^{t}\left(x_{s}, y_{s}\right)= & \text { Efficiency of conversion of input } \\
& \text { in period } s \text { to output in period } s \\
\neq & d_{o}^{s}\left(x_{s}, y_{s}\right) .
\end{aligned}
$$

Malmquist productivity index is a geometric average of the efficiency and technical changes in the two periods being considered. Following Grosskopf et al. [17], the Malmquist productivity index in (3.15) in [17] can thus be written as

$$
\begin{aligned}
\text { MPI } & =\frac{d_{o}^{t}\left(x_{t}, y_{t}\right)}{d_{o}^{s}\left(x_{s}, y_{s}\right)}\left[\frac{d_{o}^{s}\left(x_{s}, y_{s}\right)}{d_{o}^{t}\left(x_{s}, y_{s}\right)} \times \frac{d_{o}^{s}\left(x_{t}, y_{t}\right)}{d_{o}^{s}\left(x_{t}, y_{t}\right)}\right]^{1 / 2} \\
& =\text { Efficiency change } \times \text { Technical change }
\end{aligned}
$$

Malmquist productivity indices were used to estimate changes in the overall productivity of each pharmaceutical company over time. MPI > 1 means that productivity increases; MPI = 1 means that productivity does not change; MPI $<1$ indicates that productivity decreases.

Efficiency change is called "catch-up effect" and the efficiency change term relates to the degree to which a DMU improves or worsens its efficiency. Efficiency change $>1$ indicates progress in relative efficiency from period $s$ to $t$, while efficiency change $=1$ and efficiency change $<1$, respectively, indicate no change and regress in efficiency.

Technical change is called "frontier-shift effect" (or innovation effect). The technical change term reflects the change in the efficient frontiers between the two time periods. Technical change $>1$ stands for technical progress; technical change $<1$ shows technical regress.

\section{Empirical Result and Analysis}

This study utilizes the realistic financial data collected from market observation system for methodology implementation. The latest data was applied for DEA super SBM model. Meanwhile, the least 5 year data was applied for methodology implementation of Malmquist index model as these methods have different purposes on their respective analysis perspectives.

Table 2 specifies the real market data for all companies (DMU's) for the last year listing data of March 2012. This data 
TABle 2: Initial realistic data of companies: March 2012.

\begin{tabular}{lccccc}
\hline & (I) Total assets & (I) Total expenses & (I) Employee cost & (O) Total income & (O) Operating profit \\
\hline DMU 1 & 618.92 & $2,127.17$ & 140.82 & $2,337.30$ & 157.03 \\
DMU 2 & $36,160.30$ & $208,707.72$ & $2,261.07$ & $214,276.35$ & $3,866.85$ \\
DMU 3 & $7,220.90$ & $40,902.51$ & 253.21 & $41,368.31$ & 401.16 \\
DMU 4 & $1,844.03$ & $2,982.17$ & 541.69 & $3,907.79$ & 716.65 \\
DMU 5 & $26,971.33$ & $34,823.54$ & 678.00 & $41,270.76$ & $6,070.84$ \\
DMU 6 & $40,601.77$ & $175,513.48$ & $1,583.10$ & $180,585.38$ & $4,046.31$ \\
DMU 7 & $128,200.63$ & $423,238.16$ & $4,980.06$ & $437,172.01$ & $18,443.65$ \\
DMU 8 & $117,456.76$ & $40,036.21$ & $6,796.05$ & $84,199.96$ & $36,570.22$ \\
DMU 9 & $17,731.47$ & $12,549.14$ & $1,517.54$ & $18,669.19$ & $4,674.68$ \\
DMU 10 & $12,980.92$ & $52,307.10$ & 160.64 & $54,267.87$ & 1613.39 \\
\hline
\end{tabular}

TABLE 3: Statistics of latest information: March 2012.

\begin{tabular}{lccccc}
\hline & Total assets & Total expenses & Employee cost & Total income & Operating profit \\
\hline Max & 83100.12 & 237990.89 & 5843.27 & 252445.87 & 36570.22 \\
Min & 331.27 & 534.39 & 83.45 & 831.47 & 157.03 \\
Average & 24937.781 & 55698.227 & 1301.845 & 62469.481 & 7656.078 \\
SD & 28907.65583 & 71251.76861 & 1712.313963 & 74185.10785 & 10884.52571 \\
\hline
\end{tabular}

TABLE 4: Correlation coefficient: March 2012 data.

\begin{tabular}{lccccc}
\hline & Total assets & Total expenses & Employee cost & Total income & Operating profit \\
\hline Total assets & 1 & 0.638691472 & 0.924470351 & 0.732162037 & 0.919705011 \\
Total expenses & 0.638691472 & 1 & $\mathbf{0 . 3 1 9 0 2 5 8 6 7}$ & 0.991643276 & $\mathbf{0 . 2 8 8 6 6 2 3 1 9}$ \\
Employee cost & 0.924470351 & $\mathbf{0 . 3 1 9 0 2 5 8 6 7}$ & 1 & 0.43692631 & 0.986310318 \\
Total income & 0.732162037 & 0.991643276 & 0.43692631 & 1 & 0.409037546 \\
Operating profit & 0.919705011 & $\mathbf{0 . 2 8 8 6 6 2 3 1 9}$ & 0.986310318 & 0.409037546 & 1 \\
\hline
\end{tabular}

TABLE 5: DEA ranking of DMU's latest year (2012).

\begin{tabular}{lcc}
\hline Rank & DMU & Score \\
\hline 1 & DMU 8 & 2.6875041 \\
2 & DMU 10 & 2.4135548 \\
3 & DMU 7 & 1.5451541 \\
4 & DMU 5 & 1.4015806 \\
5 & DMU 9 & 1.1112872 \\
6 & DMU 6 & 1.0794482 \\
7 & DMU 2 & 1.0257595 \\
8 & DMU 4 & 1 \\
8 & DMU 1 & 1 \\
10 & DMU 3 & $\mathbf{0 . 3 7 2 7 6 0 1}$ \\
\hline
\end{tabular}

will give the clear idea on initial data and its diversity in nature and it also clearly gives a picture on the nature of the data.

Table 3 shows the basic statistical information of the input and output data. This would justify reason that the data can be applicable to basic statistical methods.

Table 4 indicates that both input and output variables are positively correlated even with minor correlation existing between employee costs and operating profit against total expenses indicated as 0.319025867 and 0.288662319 , respectively. From these results, we can justify the reason for why we
TABLE 6: Important results of DEA. (super SBM from March 2012 data).

\begin{tabular}{lc}
\hline No. of DMUs in data & 10 \\
No. of DMUs with inappropriate data & 0 \\
No. of evaluated DMUs & 10 \\
Average of scores & 1.363704861 \\
No. of efficient DMUs & 9 \\
No. of inefficient DMUs & 1 \\
No. of overiteration DMUs & 0 \\
\hline
\end{tabular}

use these indicators for DEA methodologies. The correlation is also very significant which will affect the performance.

The DEA super SBM model evaluates the efficiency scores as Table 5. It clearly indicates that the DMU 3 has inefficient score of 0.3727601 while the other 9 DMUs have efficiency scores of 1 or more. This means that DMU 3 (Chennai Petroleum Corporation) is considered as inefficient after this analysis.

Table 6 indicates that there is an only one inefficient DMU, DMU3, is become in-efficient after DEA adaptation. This clearly indicates that super SBM can distinguish all DMUs with significant differences on their scoring. 
TABLE 7: Consolidated DEA super SBM results for all the periods and ranking.

\begin{tabular}{lcccccccccc}
\hline & \multicolumn{1}{c}{ March 12 } & \multicolumn{2}{c}{ March 11 } & \multicolumn{2}{c}{ March 10 } & \multicolumn{2}{c}{ March 09 } & March 08 \\
\hline DMU 1 & 1 & 8 & 1 & 8 & 1 & 7 & 1 & 8 & 1 \\
DMU 2 & 1.0257595 & 7 & 1.1213597 & 5 & 1.030814 & 5 & 1.0360972 & 6 & 1.0422367 & 6 \\
DMU 3 & 0.3727601 & 10 & 0.7395838 & 10 & 0.63242 & 10 & 1.0896385 & 5 & 1.0201155 & 7 \\
DMU 4 & 1 & 8 & 1.2386099 & 4 & 1.9656867 & 2 & 1 & 8 & 1 & 8 \\
DMU 5 & 1.4015806 & 4 & 1.0234648 & 7 & 1.0268541 & 6 & 0.9320184 & 10 & 1.2216315 & 4 \\
DMU 6 & 1.0794482 & 6 & 1.0377901 & 6 & 1.0476469 & 4 & 1.145793 & 4 & 1.0794482 & 5 \\
DMU 7 & 1.5451541 & 3 & 1.4350091 & 3 & 1.4542432 & 3 & 1.4620893 & 3 & 1.4464182 & 3 \\
DMU 8 & 2.6875041 & 1 & 3.4718795 & 1 & 3.5388973 & 1 & 2.9274643 & 2 & 2.8389158 & 1 \\
DMU 9 & 1.1112872 & 5 & 0.777107 & 9 & 0.7559947 & 9 & 1.0029777 & 7 & 0.8559011 & 10 \\
DMU 10 & 2.4135548 & 2 & 2.5373827 & 2 & 1 & 7 & 9.966342 & 1 & 1.4899857 & 2 \\
\hline
\end{tabular}

TABLE 8: Catch-up or efficiency change. (March 2008 to March 2012).

\begin{tabular}{|c|c|c|c|c|c|}
\hline Catch-up & March $08 \Rightarrow$ March 09 & March $09 \Rightarrow$ March 10 & March $10 \Rightarrow$ March 11 & March $11 \Rightarrow$ March 12 & Average \\
\hline DMU 1 & 1 & 1 & 1 & 1 & 1 \\
\hline DMU 2 & 0.994109 & 0.994901 & 1.087839 & 1.029747 & 1.026649 \\
\hline DMU 3 & 1.068152 & 0.580394 & 1.16945 & 1.500996 & 1.079748 \\
\hline DMU 4 & 1 & 1.965687 & 0.630116 & 0.974001 & 1.142451 \\
\hline DMU 5 & 0.762929 & 1.101753 & 0.996699 & 1.221724 & 1.020776 \\
\hline DMU 6 & 1.061462 & 0.914342 & 0.990591 & 1.005124 & 0.99288 \\
\hline DMU 7 & 1.010834 & 0.994634 & 0.986774 & 1.026666 & 1.004727 \\
\hline DMU 8 & 1.031191 & 1.208861 & 0.981063 & 0.79588 & 1.004249 \\
\hline DMU 9 & 1.171838 & 0.75375 & 1.027927 & 1.169631 & 1.030787 \\
\hline DMU 10 & 6.688885 & 0.100338 & 2.537383 & 2.608928 & 2.983883 \\
\hline Average & 1.57894 & 0.961466 & 1.140784 & 1.23327 & 1.228615 \\
\hline $\operatorname{Max}$ & 6.688885 & 1.965687 & 2.537383 & 2.608928 & 2.983883 \\
\hline Min & 0.762929 & 0.100338 & 0.630116 & 0.79588 & 0.99288 \\
\hline SD & 1.798363 & 0.474362 & 0.509902 & 0.518266 & 0.618419 \\
\hline
\end{tabular}

Table 7 shows the DEA efficiency scores for the last 5 years data and ranking of DMUs by their scores. This indicates that the ranking of the industries is tending to change in a very slight manner on yearly basis. However, majority of these companies are maintaining their "efficient" levels even after yearly changes on their financial nature.

Table 8 shows the "efficiency change" of the industries over the year periods of time interval. This reveals that the efficiency changes are not so consistent due to that their nature of their financial management is not really consistently improving or not consistently outperforming DMU over the time yearly frame.

Figure 1 clearly indicats that the "efficiency changes" among the companies over the yearly time frame are exhibiting the inconsistency over the years. However, we can notice some abrupt drop of the efficiency change of DM10 (MRPL) during March 2009 to March 2010. In the following years, it has tended to increase again. But the rest of them have no such big changes even with slight changes by slight increase and decrease. This clearly indicates that the entire industry has not shown much big changes on their catch-up scores during the last 4 years. It is owing to that the financial segment is not much affected even after the global economic recession in 2007-2008.

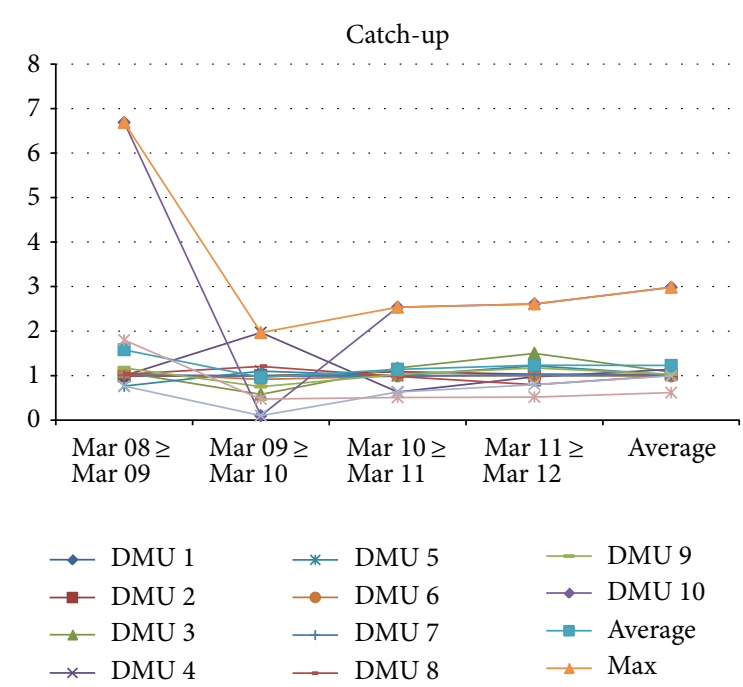

Figure 1: Catch-up or efficiency change. (March 2008 to March 2012).

Table 9 and Figure 2 indicated clearly that the companies are tending to change their level of technical changes or their 
TABLE 9: Frontier shift or technical change. (March 2008 to March 2012).

\begin{tabular}{|c|c|c|c|c|c|}
\hline Frontier & March $08 \Rightarrow$ March 09 & March $09 \Rightarrow$ March 10 & March $10 \Rightarrow$ March 11 & March $11 \Rightarrow$ March 12 & Average \\
\hline DMU 1 & 0.987134 & 1 & 1.009134 & 0.985076 & 0.995336 \\
\hline DMU 2 & 1.003373 & 0.792531 & 1.140326 & 1.207995 & 1.036056 \\
\hline DMU 3 & 1.004948 & 0.818433 & 1.092449 & 0.821111 & 0.934235 \\
\hline DMU 4 & 0.951497 & 0.821484 & 1.29312 & 0.760486 & 0.956647 \\
\hline DMU 5 & 1.086112 & 0.933236 & 0.942566 & 0.940265 & 0.975545 \\
\hline DMU 6 & 0.929928 & 0.800501 & 1.076819 & 1.391254 & 1.049626 \\
\hline DMU 7 & 0.954895 & 0.97257 & 1.041568 & 1.285798 & 1.063708 \\
\hline DMU 8 & 1.083658 & 1.069626 & 1.024671 & 0.887563 & 1.016379 \\
\hline DMU 9 & 0.928063 & 1.093942 & 0.991948 & 0.923826 & 0.984445 \\
\hline DMU 10 & 0.501099 & 2.562599 & 0.673974 & 0.673993 & 1.102916 \\
\hline Average & 0.943071 & 1.086492 & 1.028657 & 0.987737 & 1.011489 \\
\hline Max & 1.086112 & 2.562599 & 1.29312 & 1.391254 & 1.102916 \\
\hline Min & 0.501099 & 0.792531 & 0.673974 & 0.673993 & 0.934235 \\
\hline SD & 0.165187 & 0.530562 & 0.157735 & 0.234379 & 0.052098 \\
\hline
\end{tabular}

TABLE 10: Malmquist productivity index (MPI) scores. (March 2008 to March 2012).

\begin{tabular}{|c|c|c|c|c|c|}
\hline Malmquist & March $08 \Rightarrow$ March 09 & March $09 \Rightarrow$ March 10 & March $10 \Rightarrow$ March 11 & March $11 \Rightarrow$ March 12 & Average \\
\hline DMU 1 & 0.987134 & 1 & 1.009134 & 0.985076 & 0.995336 \\
\hline DMU 2 & 0.997462 & 0.788489 & 1.240491 & 1.24393 & 1.067593 \\
\hline DMU 3 & 1.073437 & 0.475014 & 1.277565 & 1.232484 & 1.014625 \\
\hline DMU 4 & 0.951497 & 1.61478 & 0.814815 & 0.740714 & 1.030451 \\
\hline DMU 5 & 0.828627 & 1.028195 & 0.939455 & 1.148744 & 0.986255 \\
\hline DMU 6 & 0.987084 & 0.731932 & 1.066688 & 1.398383 & 1.046022 \\
\hline DMU 7 & 0.965241 & 0.967351 & 1.027792 & 1.320085 & 1.070117 \\
\hline DMU 8 & 1.117459 & 1.293029 & 1.005266 & 0.706393 & 1.030537 \\
\hline DMU 9 & 1.087539 & 0.824559 & 1.01965 & 1.080536 & 1.003071 \\
\hline DMU 10 & 3.351792 & 0.257125 & 1.710131 & 1.7584 & 1.769362 \\
\hline Average & 1.234727 & 0.898047 & 1.111099 & 1.161474 & 1.101337 \\
\hline $\operatorname{Max}$ & 3.351792 & 1.61478 & 1.710131 & 1.7584 & 1.769362 \\
\hline Min & 0.828627 & 0.257125 & 0.814815 & 0.706393 & 0.986255 \\
\hline SD & 0.748337 & 0.38537 & 0.249313 & 0.311165 & 0.236437 \\
\hline
\end{tabular}

innovation effect inconsistently. This is almost like the same effect in the previous "efficiency change" level. Notably, all the companies (DMUs) have very close efficiency scores except some abrupt changes on DMU 10's efficiency over the beginning years.

Table 10 and Figure 3 are showing the Malmquist Productivity Index (MPI) scores and their changes on a yearly basis. Say for instance, the MPI scores of DMU 4, DMU 5, and DMU 8 are getting better from March 2008 to March 2009. But DMU 1, DMU 7, DMU 8 have also increased their MPI scores but very slightly. And the DMU 2, DMU 3, DMU 6, DMU 9, and DMU 10 have shown a decrement of their productivity index scores.

\section{Conclusions and Discussions}

The ranking of super SBM model shows the order of performance scores from ONGC in the top position followed by MRPL, IOCL, and GAIL. The lower to higher scores of DEA scoring order will lie as CPCL, Balmer Lawrie \& Refineries Limited, EIL, BPCL, and HPCL. It also shows that CPCL is inefficient DMU, so that it needs a very serious improvement action. Since super SBM model can distinguish the ranking of all DMUs, we would derive a clear decision for improving the performance of less efficiency scored DMUs.

After applying MPI methodology to our data set and calculating the efficiency scores, we have found that all companies in the industry have not shown many abrupt changes on their scores and it is always not consistently good or consistently standing out. So it means that there are not many changes happening on Indian stock markets even with financial crisis in a broad context.

This study provides many significant and noticeable results after applying each methodology for making necessary decisions on the respective concerns. This completed and integrated numerical study gives us better insights through the integration method as it minimizes the methodology limitation problems. 


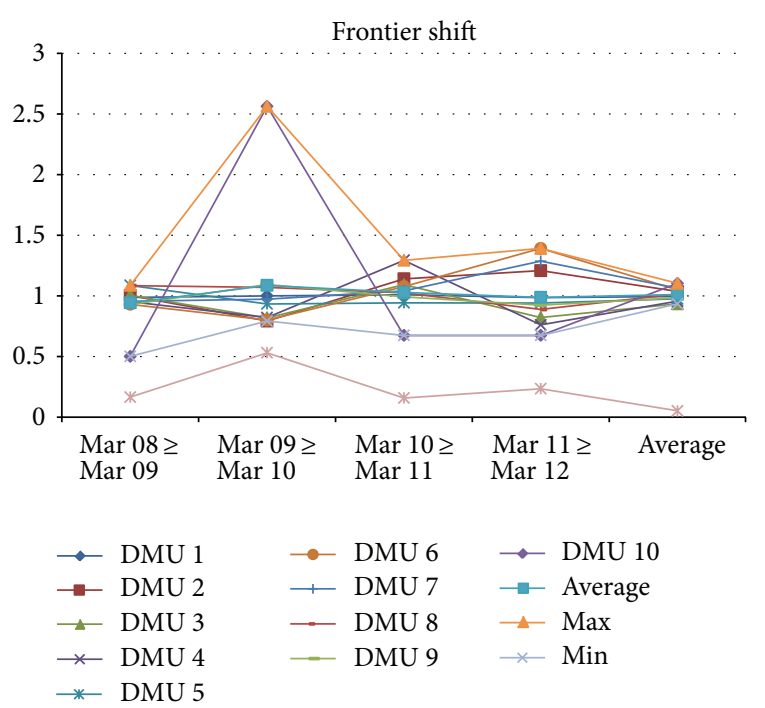

FIGURE 2: Frontier shift or technical change. (March 2008 to March 2012).

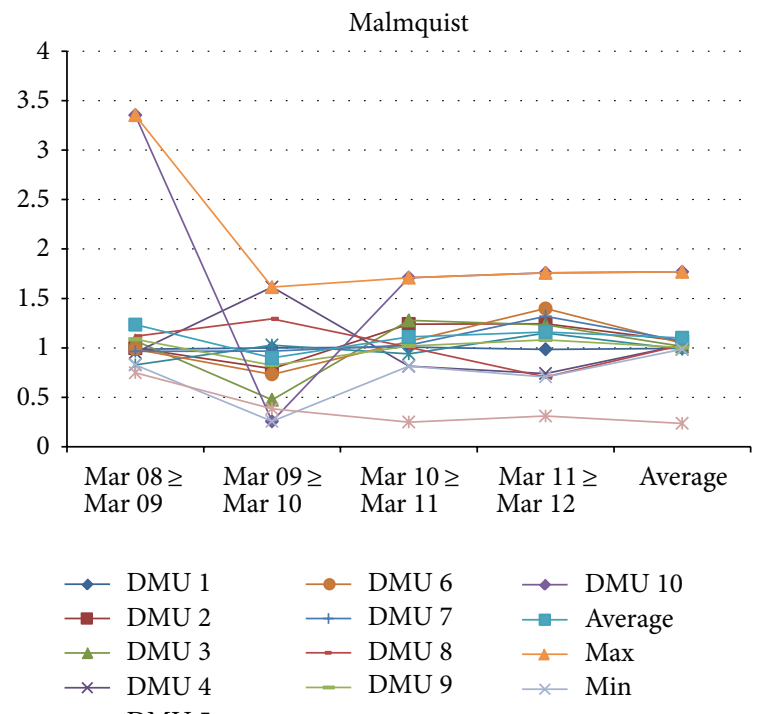

FIGURE 3: Malmquist productivity index (MPI) scores.

It gives better insights in terms of understanding the impact of global economic recession and its consequences in India as it is a core industry of the economy. This also makes this research as a considerable study for global economic outlook planners and researchers.

We suggest that this work could be used as a better model for performance analysis among the decision makers of varied industries. However, the completely integrated performance analysis model needs a detailed reevaluation in terms of the type of Industry that it can be applied to, the nature of the input data, adoptability of data for each method, applicability of each method, and so on. The future directions can also be suggested for including or avoiding different methodologies in this completely integrated model.

\section{Acknowledgments}

The authors gratefully acknowledge Dr. Chung Yi Shun from the National Cheng Kung University (NCKU) and Mr. Chuang Yun Chung from the Metal Industries Research \& Development Centre (MIRDC) for their comments on earlier versions of the paper.

\section{References}

[1] C. Kroeze, J. Vlasblom, J. Gupta, C. Boudri, and K. Blok, "The power sector in China and India: greenhouse gas emissions reduction potential and scenarios for 1990-2020," Energy Policy, vol. 32, no. 1, pp. 55-76, 2004.

[2] B. Eichengreen and H. Tong, "Is China's FDI coming at the expense of other countries?" Journal of the Japanese and International Economies, vol. 21, no. 2, pp. 153-172, 2007.

[3] B. van Ruijven and D. P. van Vuuren, "Oil and natural gas prices and greenhouse gas emission mitigation," Energy Policy, vol. 37, no. 11, pp. 4797-4808, 2009.

[4] C. Sun, "Assessing Taiwan financial holding companies'performance using window analysis and malmquist productivity index," African Journal of Business Management, vol. 5, no. 26, pp. 10508-10523, 2011.

[5] M. E. H. Arouri, A. Lahiani, A. Lévy, and D. K. Nguyen, "Forecasting the conditional volatility of oil spot and futures prices with structural breaks and long memory models," Energy Economics, vol. 34, no. 1, pp. 283-293, 2012.

[6] N. K. Nomikos and P. K. Pouliasis, "Forecasting petroleum futures markets volatility: the role of regimes and market conditions," Energy Economics, vol. 33, no. 2, pp. 321-337, 2011.

[7] A. Charnes, W. W. Cooper, and E. Rhodes, "Measuring the efficiency of decision making units," European Journal of Operational Research, vol. 2, no. 6, pp. 429-444, 1978.

[8] M. J. Farrell, “The measurement of productive efficiency," Journal of the Royal Statistical Society A, vol. 120, no. 3, pp. 253-290, 1957.

[9] L. Lindholt and S. Glomsrød, "The arctic: no big bonanza for the global petroleum industry," Energy Economics, vol. 34, no. 5, pp. 1465-1474, 2012.

[10] C.-H. Lai and M.-Y. Wei, "A common weighted performance evaluation process by using data envelopment analysis models," in Proceedings of the IEEE International Conference on Industrial Engineering and Engineering Management (IEEM '07), pp. 827831, Singapore, December 2007.

[11] S.-F. Lo and W.-M. Lu, "An integrated performance evaluation of financial holding companies in Taiwan," European Journal of Operational Research, vol. 198, no. 1, pp. 341-350, 2009.

[12] Z. Zhu, L. Liu, and J. Wang, "Optimization of China's strategic petroleum reserve policy: a markovian decision approach," Computers and Industrial Engineering, vol. 63, no. 3, pp. 626633, 2012.

[13] C. D. Ittner and D. F. Larcker, "Are nonfinancial measures leading indicators of financial performance? An analysis of customer satisfaction," Journal of Accounting Research, vol. 36, pp. $1-35,1998$.

[14] K. Tone, "A slacks-based measure of efficiency in data envelopment analysis," European Journal of Operational Research, vol. 130, no. 3, pp. 498-509, 2001.

[15] K. Tone, "A slacks-based measure of super-efficiency in data envelopment analysis," European Journal of Operational Research, vol. 143, no. 1, pp. 32-41, 2002. 
[16] D. W. Caves, L. R. Christensen, and W. E. Diewert, "The economic theory of index numbers and the measurement of input, output, and productivity," Econometrica, vol. 50, pp. 1393-1414, 1982.

[17] R. Färe, S. Grosskopf, M. Norris, and Z. Z. Zhongyang Zhang, "Productivity growth, technical progress, and efficiency change in industrialized countries," The American Economic Review, vol. 84, no. 1, pp. 66-83, 1994. 


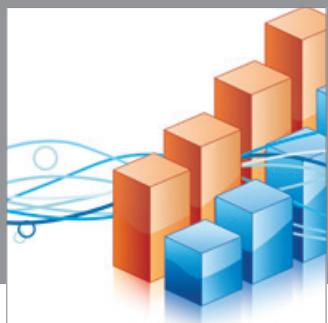

Advances in

Operations Research

mansans

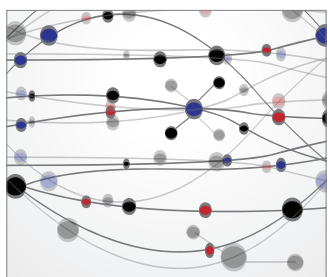

The Scientific World Journal
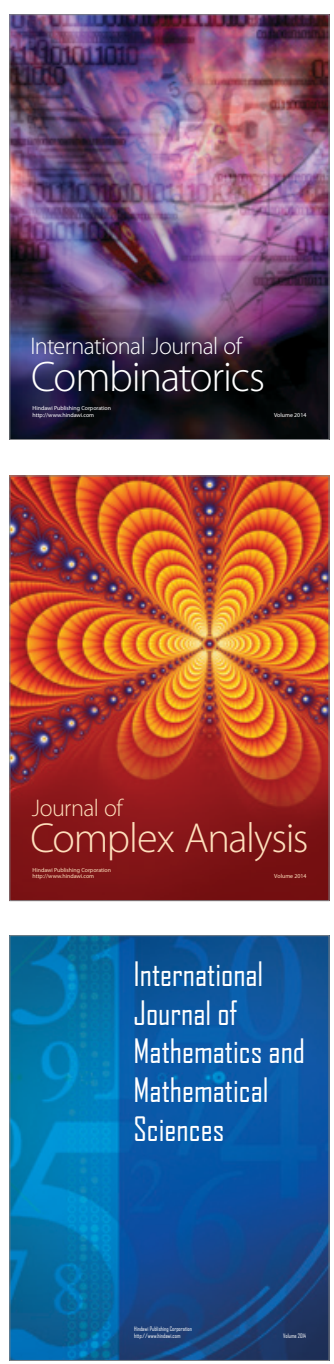
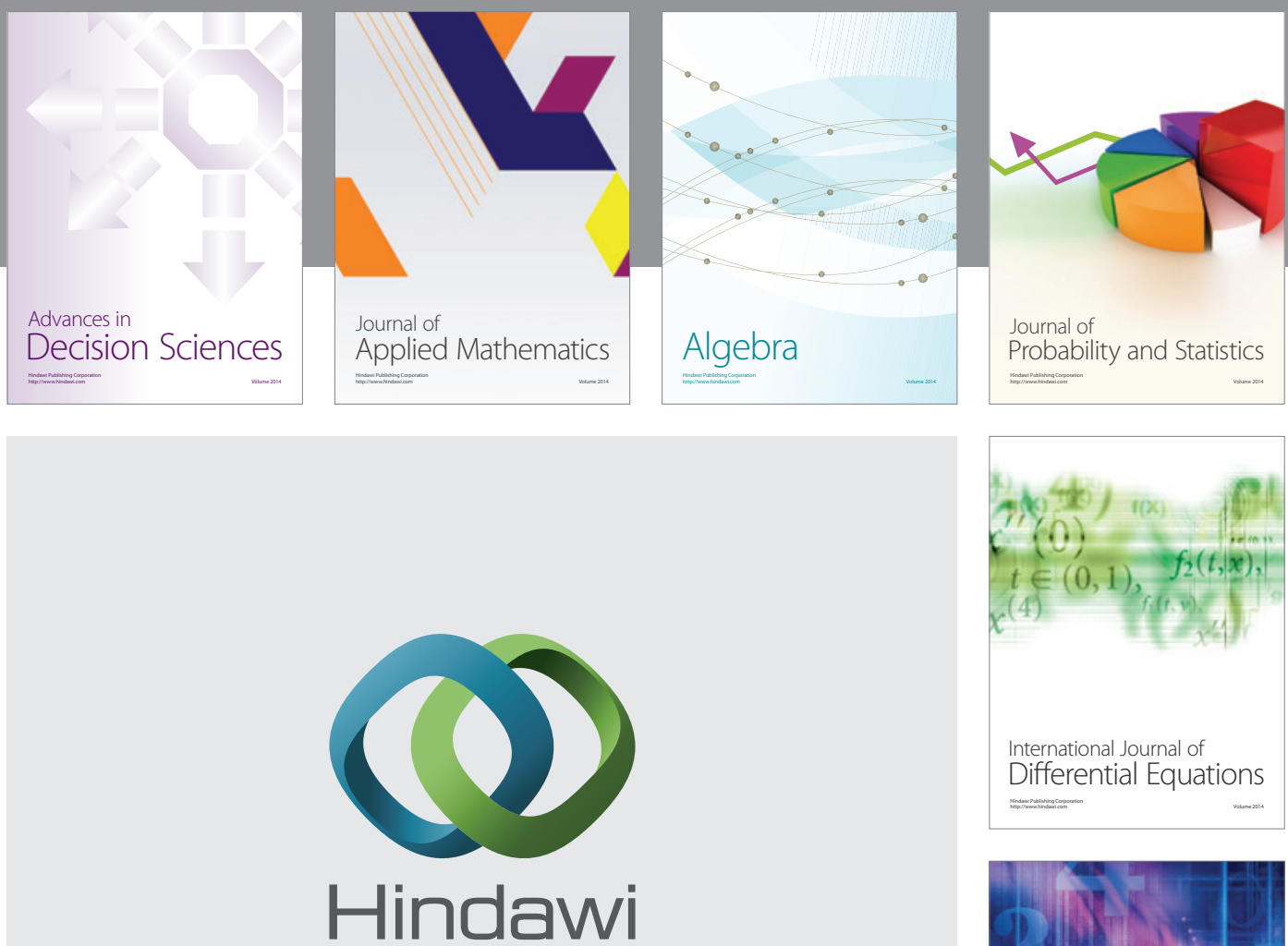

Submit your manuscripts at http://www.hindawi.com
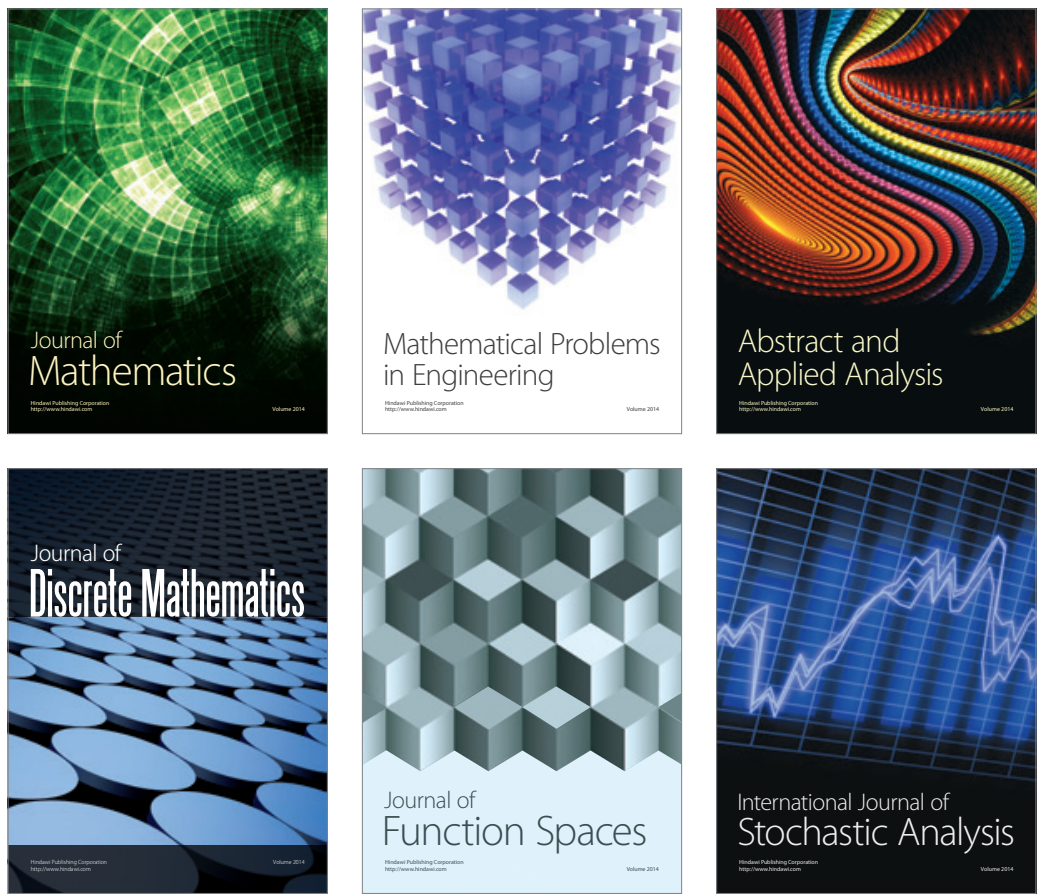

Journal of

Function Spaces

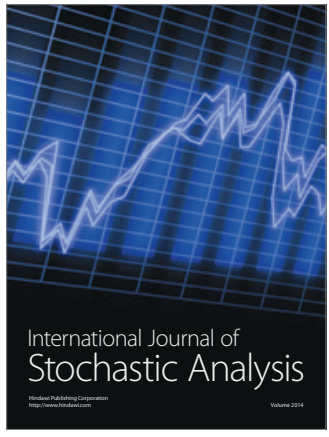

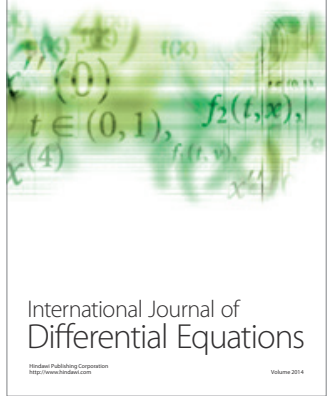
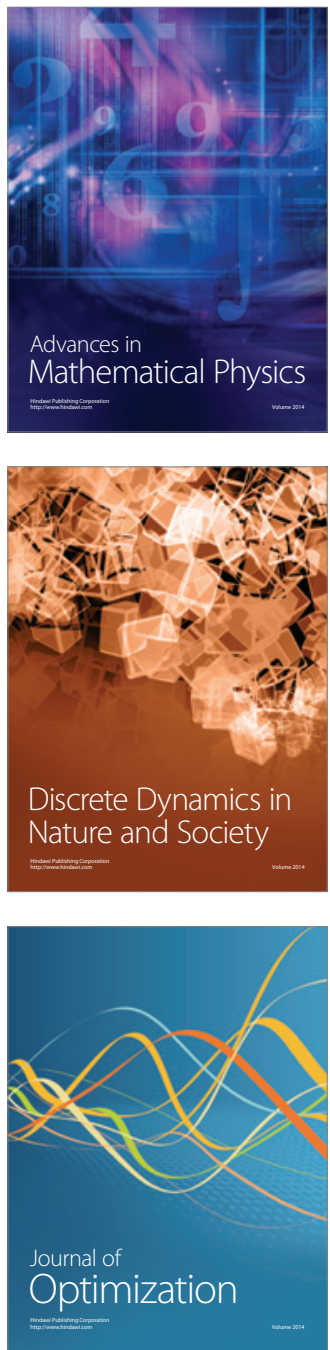